\title{
HUBUNGAN KUALITAS FISIK DEPOT AIR MINUM DENGAN KUALITAS MIKROBIOLOGI AIR MINUM DI KECAMATAN GAYAM KABUPATEN BOJONEGORO \\ Bambang Wahyudi ${ }^{1}$, Winarko ${ }^{2}$, Irwan Sulistio ${ }^{3}$ \\ ${ }^{1}$ Dinas Kesehatan Kabupaten Bojonegoro \\ 2,3 Jurusan Kesehatan Lingkungan Poltekkes Kemenkes Surabaya Email : winark00202@gmail.com
}

\begin{abstract}
ABSTRAK
Air merupakan zat yang mempunyai peranan penting untuk kehidupan makluk hidup, terutama manusia dalam proses metabolisme tubuh. Kebutuhan air semakin lama semakin meningkat sejalan dengan bertambahnya jumlah penduduk. Tingkat pencemaran air menjadi kendala dalam pengolahan air. Depot Air Minum (DAM) merupakan salah satu sumber alternatif bagi masyarakat dalam pemenuhan kebutuhan air minum seharihari. Keberadaan DAM terus meningkat sejalan dengan dinamika kebutuhan masyarakat terhadap air minum yang bermutu dan aman. Penelitian ini bertujuan menganalis hubungan kualitas sarana Depot Air Minum dengan kualitas mikrobiologi air minm di Kecamatan Gayam Kabupaten Bojonegoro tahun 2020.

Penelitian observasional dengan pendekatan cross-sectiponal ini dilaksanakan di lapangan dengan analisis secara deskriptif. Data dikumpulkan melalui observasi, penilaian, dan pengukuran di 14 Depot Air Minum di Kecamatan Gayam Kabupaten Bojonegoro diolah, dan dianalisis sesuai dengan varibel yang diteliti.

Hasil penelitian menunjukkan bahwa kualitasa fisik DAM, tidak memenuhi syarat, namun hasil pengambilan sampel dan pemeriksaan secara laboratorium menujukkan 100 $\%$ memenuhi syarat kualitas bakteriologis air minum karena ditemukan adanya bakteri coliform.

Disimpulkan bahwa kualitas fisik sarana DAM tidak berhubungan dengan kualitas bakteriologi dan disarankan kepada pengusaha depot air minum di Kecamatan Gayam diharapkan mempertahankan aspek higiene sanitasi depot yang memenuhi syarat dan memperbaiki yang tidak memenuhi syarat.
\end{abstract}

Kata Kunci : Kualitas Fisik DAM, Kualitas Bakteriologis Air

\section{PENDAHULUAN}

Minum Depot Air Minum (DAM) merupakan salah satu alternatif bagi masyarakat dalam pemenuhan kebutuhan air minum sehari-hari. Keberadaan DAM terus meningkat sejalan dengan dinamika kebutuhan masyarakat terhadap air minum yang bermutu dan aman untuk dikonsumsi meningkat, maka perlu DAM yang menghasilkan air minum yang sehat. Dengan menjamurnya usaha-usaha DAM, tidak semua DAM terjamin keamanan produknya. Sebagai fungsi air minum, air minum DAM harus memenuhi persyaratan kualitas yang telah ditetapkan. Kualitas air minum DAM masih diragukan karena diduga dapat terkontaminasi oleh berbagai cemaran yang dapat membahayakan kesehatan manusia, missal dalam penanganan dan pengolahannya yang kurang baik.
Pemeriksaan kualitas bakteriologis air minum dalam kemasan termasuk air minum DAM harus dilakukan pemeriksaan cemaran bakterinya secara berkala. Dalam lampiran Kepmenkes No. 907 tahun 2002 ditetapkan bahwa pemeriksaan kualitas bakteriologi air minum dalam kemasan atau air minum DAM disebutkan bahwa pemeriksaan bakteriologis air baku untuk air minum harus dilakukan setiap 3 bulan sekali sedangkan untuk air minum yang siap dimasukkan ke dalam kemasan minimal 1 kali setiap bulan .

Persyaratan bakteriologis untuk air ditentukan oleh kehadiran mikroorganisme yang patogen, maupun yang nonpatogen. Untuk persyaratan fisik ditentukan oleh faktor-faktor kekeruhan, warna, bau, maupun rasa. Sedangkan 
untuk persyaratan kimia air minum, perhatian diarahkan pada toksisitas bahan-bahan kimia tersebut (Riyadi, 1984).

Salah satu parameter dalam air adalah jumlah bakteri Coliform atau yang lebih sering disebut dengan Coliform yang diperbolehkan adalah 0/100 $\mathrm{ml}$ sampel (Permenkes No. 32 Tahun 2017). Mengkonsumsi air minum yang mengandung bakteri tersebut dapat berakibat timbulnya penyakit. Menurut Widiyanti dan Ristanti (2004) bahwa Coliform adalah salah satu jenis spesies utama bakteri gram negatif. Pada umumnya bakteri-bakteri yang ditemukan oleh Theodor Escherichia ini, dapat menyebabkan masalah bagi kesehatan bagi manusia seperti diare, muntaber dan masalah pencernaan lainnya.

Menurut organisasi kesehatan dunia (WHO), kurang lebih sepertiga penduduk dunia menderita berbagai penyakit yang ditularkan melalui air minum yang terkontaminasi oleh mikroorganisme. Setiap tahun sekitar 13 juta orang meninggal akibat infeksi yang berasal dari air minum, 2 juta diantaranya adalah bayi dan anak-anak. Mengkonsumsi air yang terkontaminasi oleh mikroorganisme patogen, baik air minum atau air yang ditambahkan ke dalam makanan, dapat menimbulkan berbagai penyakit gastrointestinal.

Beberapa tahun terakhir ini usaha DAM telah berkembang pesat di wilyah kabupaten Bojonegoro termasuk di kecamatan Gayam . Selain mudah diperoleh, praktis dan harga air minum isi ulang relatif lebih murah. Dengan alasan tersebut masyarakat kecamatan Gayam memilih mengkonsumsi air dari DAM untuk pemenuhan konsumsi air minum sehari-hari, namun usaha DAM masih ada yang belum memenuhi kualitas air minum khususnya kualitas secara mikrobiologis. Di Kecamatan Gayam ada 14 DAM. Dari 14 DAM tersebut, hasil pemeriksaan kualitas air semuanya memenuhi syarat, tidak ada cemaran bakteri coliform, namun pada pemeriksaan fisik sarana DAM, sebagian besar pengusaha DAM kurang menjaga kebersihan ,sehingga dalam catatan laporan Inspeksi Kesehatan Lingkungan (IKL) sebagian besar DAM secara fisik perlu adanya peningkatan pemeliharaan Sarana DAM, sehingga tidak menjadi penyebab menurunnya kualitas air DAM. Penelitian ini bertujuan Untuk Menganalis hubungan kualitas sarana DAM dengan kualitas mikrobilogi air minum DAM di wilayah Kecamatan Gayam.

\section{METODOLOGI PENELITIAN}

Penelitian observasional dengan pendekatan cross-sectiponal ini dilaksanakan di lapangan dengan analisis secara deskriptif., Data dikumpulkan melalui observasi, penilaian, dan pengukuran dan-di 14 Depot Air Minum di Kecamatan Gayam Kabupaten Bojonegoro diolah, dan dianalisis sesuai dengan varibel yang diteliti. Evaluasi hasil penilaian variabel dilakukan melalui perbandingkan dengan standar Higiene Sanitasi DAM menurut Keputusan Menteri Perindustrian dan Perdagangan Nomor 651 Tahun 2004 dan data hasil pemeriksaan kualitas mikrobiologi Coliform berdasarkan Peraturan Menteri Kesehatan Republik Indonesia Nomor 492/Menkes/PER/IV/2010.

Air baku pada sampling Depot Air Minum di Kecamatan Gayam berasal dari sumber mata air pegunungan dari kabupaten Ngawi. Air baku diangkut menggunakan mobil tangki aluminium yang didalamnya berlapis steinless steel. Berikut hasil pemeriksaan kualitas air pada depot. 
Tabel 1

Hasil Pemeriksaan Air Depot Air Minum Di wilayah Kec. Gayam Bojonegoro 2020

\begin{tabular}{|c|c|c|c|c|c|c|c|c|c|}
\hline \multirow[t]{2}{*}{ DAM } & \multirow[t]{2}{*}{ Sumber air Baku } & \multicolumn{3}{|c|}{ Kualitas fisik air minum } & \multicolumn{3}{|c|}{$\begin{array}{c}\text { Kualitas Biologi air Kualitas } \\
\text { Biologi air minum }\end{array}$} & \multicolumn{2}{|c|}{$\begin{array}{l}\text { Kualitas Kimia } \\
\text { air minum }\end{array}$} \\
\hline & & Bau & Rasa & Kriteria & coliform & e-coli & kriteria & $\mathrm{pH}$ & kriteria \\
\hline DAM EL TIRTA & $\begin{array}{l}\text { Air Mata } \\
\text { Pegunungan } \\
\text { Ngawi }\end{array}$ & tidak & tidak & MS & 0 & 0 & MS & 6,9 & MS \\
\hline $\begin{array}{l}\text { DAM KEMPIT } \\
\text { BERDIKARI }\end{array}$ & $\begin{array}{l}\text { Air Mata } \\
\text { Pegunungan } \\
\text { Ngawi }\end{array}$ & tidak & tidak & MS & 0 & 0 & MS & 7,2 & MS \\
\hline $\begin{array}{l}\text { DAM AZZM } \\
\text { TIRTA }\end{array}$ & $\begin{array}{l}\text { Air Mata } \\
\text { Pegunungan } \\
\text { Ngawi }\end{array}$ & tidak & tidak & MS & 0 & 0 & MS & 6,8 & MS \\
\hline $\begin{array}{l}\text { DAM AL- } \\
\text { BAROKAH }\end{array}$ & $\begin{array}{l}\text { Air Mata } \\
\text { Pegunungan } \\
\text { Ngawi }\end{array}$ & tidak & tidak & MS & 0 & 0 & MS & 6,6 & MS \\
\hline $\begin{array}{l}\text { DAM GEO } \\
\text { TIRTA }\end{array}$ & $\begin{array}{l}\text { Air Mata } \\
\text { Pegunungan } \\
\text { Ngawi }\end{array}$ & tidak & tidak & MS & 0 & 0 & MS & 7 & MS \\
\hline DAM AL-AMIN & $\begin{array}{l}\text { Air Mata } \\
\text { Pegunungan } \\
\text { Ngawi }\end{array}$ & tidak & tidak & MS & 0 & 0 & MS & 6,7 & MS \\
\hline $\begin{array}{l}\text { DAM TIRTA } \\
\text { ABADI }\end{array}$ & $\begin{array}{l}\text { Air Mata } \\
\text { Pegunungan } \\
\text { Ngawi }\end{array}$ & tidak & tidak & MS & 0 & 0 & MS & 6,9 & MS \\
\hline $\begin{array}{l}\text { DAM AQILA } \\
\text { TIRTA }\end{array}$ & $\begin{array}{l}\text { Air Mata } \\
\text { Pegunungan } \\
\text { Ngawi }\end{array}$ & tidak & tidak & MS & 0 & 0 & MS & 6,6 & MS \\
\hline $\begin{array}{l}\text { DAM LUSI } \\
\text { TIRTA }\end{array}$ & $\begin{array}{l}\text { Air Mata } \\
\text { Pegunungan } \\
\text { Ngawi }\end{array}$ & tidak & tidak & MS & 0 & 0 & MS & 6,8 & MS \\
\hline $\begin{array}{l}\text { DAM FALIHA } \\
\text { MINERAL }\end{array}$ & $\begin{array}{l}\text { Air Mata } \\
\text { Pegunungan } \\
\text { Ngawi }\end{array}$ & tidak & tidak & MS & 0 & 0 & MS & 6,4 & MS \\
\hline $\begin{array}{l}\text { DAM ALISIA } \\
\text { TIRTA }\end{array}$ & $\begin{array}{l}\text { Air Mata } \\
\text { Pegunungan } \\
\text { Ngawi }\end{array}$ & tidak & tidak & MS & 0 & 0 & MS & 6,6 & MS \\
\hline $\begin{array}{l}\text { DAM DIAN } \\
\text { TIRTA }\end{array}$ & $\begin{array}{l}\text { Air Mata } \\
\text { Pegunungan } \\
\text { Ngawi }\end{array}$ & tidak & tidak & MS & 0 & 0 & MS & 7,2 & MS \\
\hline $\begin{array}{l}\text { DAM EDY } \\
\text { STAR }\end{array}$ & $\begin{array}{l}\text { Air Mata } \\
\text { Pegunungan } \\
\text { Ngawi }\end{array}$ & tidak & tidak & MS & 0 & 0 & MS & 6,8 & MS \\
\hline $\begin{array}{l}\text { DAM DITA } \\
\text { TIRTA }\end{array}$ & $\begin{array}{l}\text { Air Mata } \\
\text { Pegunungan } \\
\text { Ngawi }\end{array}$ & tidak & tidak & MS & 0 & 0 & MS & 6,8 & MS \\
\hline
\end{tabular}

Tabel 2

Hasil Pemeriksaan Kualitas Fisik DAM Di Kec. Gayam Bojonegor0 Tahun 2020

\begin{tabular}{clcccc}
\hline \multirow{2}{*}{ No } & \multicolumn{1}{c}{ Kondisi DAM } & \multicolumn{2}{c}{$\begin{array}{c}\text { Memenuhi } \\
\text { syarat }\end{array}$} & $\begin{array}{c}\text { Tidak } \\
\text { memenuhi } \\
\text { syarat }\end{array}$ \\
\cline { 2 - 6 } & \multicolumn{1}{c}{\begin{tabular}{c}
$\Sigma$ \\
\multicolumn{1}{c}{2}
\end{tabular}} & 3 & 4 & 5 & 6 \\
\hline 1 & Lokasi bebas dari pencemaran dan penularan penyakit & 14 & 100 & 0 & 0 \\
\hline 2 & $\begin{array}{l}\text { Bangunan Kuat, aman, mudah dibersihkan dan mudah } \\
\text { pemeliharaannya }\end{array}$ & 12 & 86 & 2 & 14 \\
\hline 3 & $\begin{array}{l}\text { Lantai kedap air, permukaan rata, halus, tidak licin, } \\
\text { tidak retak,tidak menyerap debu,dan mudah dibersihkan, } \\
\text { serta } \\
\text { kemiriringan cukup landau }\end{array}$ & 12 & 86 & 2 & 14 \\
\hline
\end{tabular}




\begin{tabular}{|c|c|c|c|c|c|}
\hline 1 & 2 & 3 & 4 & 5 & 6 \\
\hline 4 & $\begin{array}{l}\text { Dinding kedap air, permukaan rata, halus,tidak licin, tidak } \\
\text { retak, tidak menyerap debu, dan mudah dibersihkan, serta } \\
\text { warna yang cerah dan terang }\end{array}$ & 4 & 28 & 10 & 72 \\
\hline 5 & $\begin{array}{l}\text { Atap dan langit-langit harus } \\
\text { kuat, anti tikus,mudah dibersihkan, tidak menyerap debu, } \\
\text { permukaan rata, dan } \\
\text { berwarna terang, serta } \\
\text { mempunyai ketinggian cukup }\end{array}$ & 7 & 50 & 7 & 50 \\
\hline 6 & $\begin{array}{l}\text { Tata ruang terdiri atas ruang } \\
\text { proses pengolahan, penyimpanan, pembagian/penyediaan } \\
\text { dan ruang tunggu } \\
\text { pengunjung/konsumen. }\end{array}$ & 4 & 28 & 10 & 72 \\
\hline 7 & $\begin{array}{l}\text { Pencahayaan cukup terang } \\
\text { untuk bekerja,tidak menyilaukan dan tersebar secara } \\
\text { merata. }\end{array}$ & 14 & 100 & 0 & 0 \\
\hline 8 & Ventilasi menjamin peredaran / pertukaran udara yang baik. & 14 & 100 & 0 & 0 \\
\hline 9 & $\begin{array}{l}\text { Kelembaban udara dapat memberikan mendukung } \\
\text { kenyamanan dalam melakukan pekerjaan/aktivitas (RH ; } \\
45 \%-65 \%)\end{array}$ & 11 & 78 & 3 & 22 \\
\hline 10 & Memiliki akses kamar mandi dan jamban. & 0 & 0 & 14 & 100 \\
\hline 11 & $\begin{array}{l}\text { Terdapat saluran pembuangan air limbah yang alirannya } \\
\text { lancar dan tertutup }\end{array}$ & 2 & 14 & 12 & 86 \\
\hline 12 & Terdapat tempat sampah yang tertutup & 5 & 35 & 9 & 65 \\
\hline 13 & $\begin{array}{l}\text { Terdapat tempat cuci tangan yang dilengkapi air mengalir } \\
\text { dan sabun }\end{array}$ & 10 & 71 & 4 & 29 \\
\hline 14 & $\begin{array}{l}\text { Bebas dari tikus, kecoa, dan } \\
\text { Lalat }\end{array}$ & 8 & 57 & 6 & 43 \\
\hline
\end{tabular}

Berdasarkan tabel 1 dan tabel 2 mengenai hasil sampel air minum DAM dan hasil IKL DAM di Kecamatan Gayam di dapatkan hasil berikut :

1. Kualitas Air minum DAM

Bahan baku utama yang digunakan untuk air minum harus air yang diambil dari sumber yang terjamin kualitasnya. Hasil penelitian menunjukkan, sampel air minum pada 14 Depot Air Minum berasal dari sumber yang sama yaitu mata air pegunungan Ngawi. Hasil observasi, pada pemeriksaan kualitas secara fisika air minum pada DAM tersebut memenuhi syarat kesehatan , tidak berbau, tidak berasa dan tidak bewarna

Kualitas Bakteriologi hasil uji laboratorium sample air minum pada 14 DAM menunjukkan bahwa semua sample air minum tersebut memenuhi syarat (tidak terdapat kandungan bakteri Coliform). Meski demikian Depot Air Minum harus tetap menjaga kualitas air baku dengan melakukan pengawasan internal (pemeriksaan rutin).

Baku mutu yang dipersyaratkan menurut Permenkes 32 tahun 2017 adalah satandart baku mutu (kadar maksimum) Total Coliform 50 CFU/100ml. dan E-coly 0 CFU/100ml

\section{Pemeriksaan IKL DAM}

Ada beberapa hal yang dapat mempengaruhi kualitas air minum yaitu hygiene dan sanitasi depot, sarana pengolahan, dan proses pengolahan air minum isi ulang. Depot Air Minum (DAM) yang tidak memenuhi syarat, kurang menjaga hygiene dan sanitasi depot terutama dalam hal tempat dan lokasi.

Berdasarkan hasil pemeriksaan IKL bahwa 14 depot air minum yang ada di Kecamatan Gayam kondisi lingkungannya sudah memenuhi 
syarat baik dari segi lokasi, pencahayaan dan ventilasi. untuk bangunan, lantai, dinding, atap, langitlangit, kelembaban, fasilitas kamar mandi dan jamban, saluran pembuangan air limbah, dan bebas dari tikus, kecoa, dan lalat tidak memenuhi syarat. Ada juga yang tidak memenuhi syarat ada beberapa DAM yaitu : tidak terdapat tata ruang pengolahan air minum, tidak terdapat tempat sampah, dan tidak terdapat tempat cuci tangan yang dilengkapi dengan air mengalir serta sabun.

\section{KESIMPULAN DAN SARAN \\ Kesimpulan}

Dari hasil penelitian dapat disimpulkan bahwa :

1. Kondisi lingkungan DAM di Kecamatan Gayam 100 \% memenuhi syarat.

2. Kualoitas fisik peralatannya $71 \%$ memenuhi syarat, sedangkan $29 \%$ belum memenuhi syarat.

3. Sumber air baku DAM di Kecamatan Gayam Bojonegoro $100 \%$ berasal dari mata air Pegunungan Ngawi.

4. Kondisi higiene karyawan DAM di Kecamatan Gayam Bojonegoro 100 $\%$ memenuhi syarat.

5. Kualitas fisik peralatan DAM tidak berhubungan dengan kualitas bakteriologi

\section{Saran}

Berdasarkan hasil penelitian, maka saran dari penulis adalah :

1. Bagi pengusaha DAM yang ada di Kecamatan Gayam diharapkan mempertahankan aspek-aspek higiene sanitasi depotnya yang memenuhi syarat kesehatan agar konsumen aman meminum air produksi depotnya dan meningkatkan kuliata peralatan yang masih kurang serta karyawan agar menggunakan pakaian kerja, dan tidak pernah mencuci tangan saat sebelum melakukan pengisian galon.

2. Bagi masyarakat diharapkan dapat memenuhi kebutuhan air minum pada DAM yang yang memenuhi syarat kesehatan
3. Bagi petugas sanitarian Puskesmas Gayam sebagai pihak berwenang disarankan melakukan pengawasan dan pembinaan lebih ketat terhadap pengusaha dan karyawan DAM yang ada di Kecamatan Gayam serta mengadakan pelatihan/kursus ulang tentang bagaimana menjamah makanan dan minuman yang memenuhi syarat kesehatan agar mutu produk yang dihasilkan terkontrol dengan baik dan sesuai dengan standar mutu yang telah ditetapkan..

4. Bagi peneliti diharapkan dengan penelitian tersebut dapat membantu menciptakan kondisi DAM yang memenuhi syarat kesehatan di wilayah kecamatan Gayam

\section{DAFTAR PUSTAKA}

Keputusan Menteri Perindustrian dan Perdagangan No. 651 Tahun 2004 tentang Persyaratan Teknis Depot Air Minum dan Perdagangannya. Jakarta: Departemen Perindustrian dan Perdagangan RI

Latif, Iin Wahyuni., 2012. Studi Kualitas Air Minum Isi Ulang Ditinjau dari Proses Ozonisasi, Ultraviolet dan Reversed Osmosis Di Kecamatan Kota Tengah dan Kecamatan Kota Selatan Kota Gorontalo. Skripsi Jurusan Kesehatan Masyarakat Fakultas Ilmu-ilmu Kesehatan dan Keolahragaan, Universitas Gororntalo (tidak dipublikasikan).

Pandiangan, Masta Parulian. 2012. Pertanggungjawaban

Produsen Air Minum Isi Ulang Terhadap Konsumen. Skripsi Fakultas Hukum Universitas Simalungun PematangSiantar (Tidak dipublikasikan).

Peraturan Menteri Kesehatan No. 43 Tahun 2014 tentang Hygiene Sanitasi Depot Air Minum. Jakarta: Menkes

Peraturan Menteri Kesehatan No. 32 Tahun 2017 tentang Standar Baku Mutu Kesehatan Lingkungan Dan Persyaratan Kesehatan Air Untuk Keperluan Higiene Sanitasi, Kolam Renang, Solus Per Aqua, Dan 
Pemandian Umum. Jakarta: Menkes

Pradana, Yoga Ardy dan Bowo Djoko Marsono. 2013. Uji Kualitas Air Minum Isi Ulang di Kecamatan Sukodono, Sidoarjo Ditinjau dari Perilaku dan Pemeliharaan Alat. Jurnal Teknik Pomits Vol.2, No.2

Radji, M., Heria., Herman, 2008. Pemeriksaan Bakteriologis Air minum di Beberapa Depo Air minum di Daerah Lenteng Agung dan Srengseng Sawah Jakarta Selatan. Majalah I/mu Kefarmasian, Vol. V, No. 2, Agustus2008, $101-$ 109. ISSN : 1693-9883

Radji, Maksum., Anglia Puspaningrum dan Atiek Suamiati. 2010. Deteksi Cepat Bakteri Escherichia coli dalam Sampel Air dengan Metode Polymerase Reaction Menggunakan Primer 16E1 dan 16E2. Makara Sains, Vol. 14, No. 1.

Randa, Mirna Sari., 2012. Analisis Bakteri Coliform (Fekal dan Non Fekal) pada Air Sumur Kompleks Roudi
Manokwari. Skripsi Program Studi Biologi Jurusan Biologi. Fakultas Matematika dan Ilmu Pengetahuan Alam Universitas Negeri Papua. Manokwari (Tidak dipublikasikan).

Sandra, Christyana dan Lilis Sulistyorini. 2007. Hubungan Pengetahuan dan Kebiasaan Konsumen Air Minum Isi Ulang Dengan Penyakit Diare. Artikel Ilmiah Fakultas Kesehatan Masyarakat Universitas Airlangga. Surabaya.

Skipton, Sharon O. 2014. Drinking Water: Bacteria. Neb Guide. University of Nebraska-Lincoln Extenstion.

Soetomo, M.S. 2003. Regulasi Air PDAM, AMDK dan Depot Air.

Widiyanti, N.L.P.M. dan N.P. Ristanti. 2004. Analisis Kualitatif Bakteri Koliform pada Depo Air Minum Isi Ulang di Kota Singaraja Bali. Jurnal Ekologi Kesehatan Vol 3 no 1.

World Health Organization (WHO). 2006. Guidelines for DrinkingWater Quality: First Addendum to Third Edition, Geneva, vol. 1. 